\title{
BANJIR ROB : POTENSI KERENTANAN LINGKUNGAN SERTA PENANGGULANGANNYA
}

\author{
Zuardin \\ Program Studi Biologi, Universitas Islam Negeri Sunan Ampel, Jl. Jend. A. Yani 117 Surabaya \\ Email:ardinph@gmail.com
}

\begin{abstract}
ABSTRAK
Banjir pasang atau yang lebih dikenal dengan istilah rob merupakan banjir yang terjadi karena naiknya air laut dan menggenangi daratan ketika air laut mengalami pasang sehingga menyebabkan kerentanan lingkungan. Namun demikian, untuk kondisi atau tempat tertentu, yaitu di daerah terbangun, banjir pasang ini terjadi menyusul perubahan penggunaan lahan dan penurunan muka tanah karena beban bangunan fisik. Kerentanan lingkungan yang dapat ditimbulkan diantaranya kerentanan fisik (physical vulnerability), kerentanan sosial (social vulnerability), serta kerentanan ekonomi (economic vulnerability). Untuk penanggulangannya dapat dilakukan dengan beberapa pendekatan diantaranya ialah ketahanan struktural, ketahanan sosial, ketahanan ekonomi, mitigasi struktural dan mitigasi non-struktural.
\end{abstract}

Kata kunci: banjir rob, kerentanan lingkungan, mitigasi bencana

\section{PENDAHULUAN}

Banjir pasang merupakan permasalahan yang sering terjadi pada daerah yang memiliki pantai yang landai dan elevasi permukaan tanah yang tidak jauh lebih tinggi dari pasang laut tertinggi. Luas daerah yang tergenang oleh banjir pasang ini ditentukan oleh ketinggian air laut pada saat pasang. Kenaikan air laut terjadi perlahan-lahan sesuai dengan gerak pasang air laut. Ketinggian air banjir sesuai dengan ketinggian air laut pasang. Selanjutnya genangan banjir ini bergerak turun ketika air laut surut. Selain itu, waktu kedatangan dan ketinggian banjir ini berubah-ubah mengikuti irama pasang-surut air laut. Demikian pula dengan luas daerah genangan atau daerah-daerah yang akan tergenang pada suatu waktu tertentu dapat diprediksi berdasarkan prediksi ketinggian air laut pasang.

Fenomena banjir rob ini banyak menimbulkan kerugian pada aspek ekonomi, sosial, infrastruktur dan kesehatan. Suryanti dan Marfai (2008) menunjukkan akibat banjir rob telah memberikan pengaruh negatif terhadap kawasan pantai, antara lain : merubah fisik lingkungan, kegiatan harian terganggu, penduduk tidak mempunyak aksesibilitas untuk pergi ke tempat kerja dan beraktifitas dengan normal, karena fasilitas jalan di kawasan pesisir tergenang air laut, pelayanan umum penunjang kegiatan rumah tangga seperti ketersediaan air bersih dan listrik tidak berfungsi. Menurut Soedarsono (1996) anak-anak juga mudah terkena penyakit dan infeksi karena genangan banjir tersebut. Penyakit seperti diare, demam dan malaria menjadi lebih mudah menyerang selama banjir karena kondisi sanitasi yang buruk. Banjir rob juga mempengaruhi kualitas bangunan atau kondisi bangunan. Akibat genangan pada bangunan secara kontinyu dengan frekuensi yang tinggi, bangunan tempat tinggal akan mengalami kerusakan.

Menghadapi karakter persoalan yang demikian, upaya yang perlu dilakukan untuk menghindar dari bahaya banjir pasang ini adalah dengan memetakan daerah-daerah pesisir yang rentan terhadap ancaman banjir dan penurunan muka tanah. Dengan adanya peta daerah ancaman bahaya tersebut diharapkan penduduk atau pengambil keputusan dapat menghindari untuk melakukan pengembangan atau pembangunan fisik di daerah rawan itu. Prinsipnya, upaya mitigasi dilakukan untuk mencegah penduduk atau pemerintah melakukan pembangunan fisik di daerah berpotensi penurunan muka tanah. Bagi daerah terbangun mengalami banjir pasang-surut dan penurunan muka tanah tersedia dua alternatif pilihan yaitu meninggalkan daerah bencana atau menanggung biaya perawatan bangunan selamanya. 


\section{METODE PENELITIAN}

\section{Identifikasi daerah rawan}

Menurut Cardona (2003) risiko bencana didefinisikan sebagai potensi kerugian baik berupa kematian, keterancaman jiwa, kerugian materi dan gangguan kegiatan sosial ekonomi masyarakat yang ditimbulkan akibat dari bencana. Smith dan Petley (2009) juga mendefinisikan penilaian risiko sebagai suatu proses evaluasi tentang pentingnya risiko, baik secara kuantitatif atau kualitatif. Penilaian risiko kuantitatif adalah proses yang dipahami oleh minoritas masyarakat dan penilaian ini belum diterapkan pada semua bahaya lingkungan. Jadi, terkadang penilaian kuantitatif hanya mengukur satu bahaya lingkungan saja. Penilaian atau analisis risiko bencana bertujuan mengindentifikasi wilayah berdasarkan tingkat risikonya terhadap bencana. Sebuah risiko bencana dibentuk paling tidak oleh dua factor yaitu dimana bencana tersebut berada, biasanya disebut tempat yang memiliki potensi bencana (hazard) dan tingkat kerentanan (vulnerability).

Bencana dapat disebabkan oleh kejadian alam (natural disaster) maupun oleh ulah tangan manusia sendiri (manmade disaster). Faktor-faktor yang dapat menyebabkan bencana, antara lain :

a. Bahaya alam (natural hazards) dan bahaya karena ulah manusia (man-made hazards) yang menurut United Nations International Strategy for Disaster Reduction (UN-ISDR) dapat dikelompokkan menjadi bahaya geologi (geological hazards), bahaya hidrometeorologi (hydrometeorological hazards), bahaya biologi (biological hazards), bahaya teknologi (technological hazards) dan penurunan kualitas lingkungan (environmental degradation);

b. Kerentanan (vulnerability) yang tinggi dari masyarakat, infrastruktur serta elemen-elemen di dalam kota/kawasan yang berisiko bencana;

c. Kapasitas yang rendah dari berbagai komponen di dalam masyarakat.

\section{Analisis bahaya}

Bahaya adalah suatu kejadian yang mengancam atau menyebabkan kerusakan secara potensial pada suatu wilayah (Pramulya 2010). Menurut Rahayu et all. (2009), bahaya atau dalam bahasa Inggris Hazard diartikan sebagai suatu kejadian yang memiliki potensi dapat menimbulkan kerugian dan ekonomi atau mengancam jiwa manusia dan kesejahteraannya bila terjadi di suatu lingkungan permukiman, budidaya atau industri. Misalnya : kejadian banjir air pasang (rob) yang masuk ke pemukiman penduduk dapat menyebabkan lingkungan permukiman menjadi kotor dan kumuh. Hal ini disebabkan oleh air rob ini bercampur dengan buangan limbah industry dan limbah rumah tangga masyarakat. Selain itu, rob mengakibatkan perubahan air tawar menjadi air asin sehingga banyak lahan pertanian dekat pantai menjadi tidak produktif.

Kajian bahaya dilakukan untuk menentukan karakteristik/ciri-ciri dari potensi bahaya dan ancaman-ancaman yang mungkin dihadapi oleh masyarakat. Oleh karena itu, perlu mengidentifikasi faktor-faktor yang berhubungan dengan bahaya. Banjir rob disebabkan oleh beberapa faktor, diantaranya yaitu :

a. Faktor-faktor alam, seperti iklim (angin, durasi dan intensitas curah hujan yang sangat tinggi), oseanografi (pasang surut dan kenaikan permukaan air laut), kondisi geomorfologi (dataran rendah/perbukitan, ketinggian, dan lereng, bentuk sungai), geologi dan genangan. Ditambah kondisi hidrologi (siklus, kaitan hulu-hilir, kecepatan aliran);

b. Kegiatan manusia yang menyebabkan terjadinya perubahan tata ruang yang berdampak pada perubahan alam. Aktivitas manusia yang sangat dinamis, seperti pembabatan hutan mangrove (bakau) untuk daerah hunian, konversi lahan pada kawasan lindung, pemanfaatan sungai/saluran untuk permukiman, pemanfaatan wilayah retensi banjir, perilaku masyarakat dan sebagainya;

c. Degradasi lingkungan seperti hilangnya tumbuhan penutup lahan pada catchment area, pendangkalan sungai akibat sedimentasi, penyempitan alur sungai dan sebagainya;

d. Jebolnya tanggul pembatas antara daratan dan lautan.

\section{Analisis tingkat kerentanan}

Kerentanan (vulnerability) adalah kondisi-kondisi yang ditentukan oleh faktor atau proses fisik, sosial, ekonomi, dan lingkungan yang meningkatkan kecenderungan (susceptibility) sebuah komunitas terhadap dampak bahaya (ISDR 2004). Tingkat kerentanan (vulnerability) merupakan suatu hal penting untuk diketahui sebagai salah satu faktor yang berpengaruh terhadap terjadinya bencana alam, karena bencana baru akan terjadi bila bahaya alam terjadi pada kondisi yang rentan (Lewis 1997). Pendapat lain menyatakan bahwa kerentanan lebih menekankan aspek manusia di tingkat komunitas yang langsung berhadapan dengan ancaman (bahaya), sehingga kerentanan menjadi faktor utama dalam suatu tatanan sosial yang memiliki risiko bencana lebih tinggi apabila tidak didukung oleh kemampuan (capacity) (Mardiatno et all, 2012). 


\section{Analisis tingkat ketahanan}

Tingkat ketahanan atau kapasitas terhadap bencana rob dapat didefinisikan sebagai suatu kombinasi antara semua kekuatan dan sumberdaya yang tersedia di dalam sebuah komunitas, masyarakat atau lembaga yang dapat mengurangi tingkat risiko atau dampak bencana $r o b$. Kapasitas ini adalah aspek-aspek positif yang dapat mengurangi risiko dengan mengurangi kerentanan yang ada.

\section{Mitigasi bencana banjir rob}

Mitigasi adalah serangkaian upaya untuk mengurangi risiko bencana, baik melalui pembangunan fisik maupun penyadaran dan peningkatan kemampuan menghadapi ancaman bencana. Upaya dalam pengurangan risiko banjir $r o b$ haruslah memadukan upaya mitigasi dan adaptasi yang terkait langsung dengan pembangunan berkelanjutan sebagai upaya untuk mengurangi risiko terhadap kerugian dan penghidupan masyarakat serta peningkatan daya tahan (resilience) masyarakat terhadap berbagai potensi bencana. Upaya tersebut harus mengintegrasikan semua sector dan melibatkan semua strakeholders (pemerintah, masyarakat dan pihak swasta). Masyarakat berusaha secara aktif mengakses berbagai informasi formal dan informal, sementara pemerintah mempersiapkan sarana, prasarana dan sumber daya yang memadai untuk pelaksanaan berbagai kegiatan pengurangan risiko bencana. Terdapat empat upaya/strategi yang dapat dilakukan masyarakat sebagai upaya dalam mengurangi kerugian yang ditimbulkan kenaikan muka air laut yaitu tidak melakukan apa-apa (do nothing), strategi adaptasi, strategi perlawanan dan strategi mundur (retreat). Secara umum, jenis-jenis mitigasi dapat dikelompokkan kedalam mitigasi struktural dan mitigasi non struktural. Upaya ini juga harus dilakukan secara fisik maupun non-fisik dengan memperhitungkan berbagai sumberdaya biotik dan kultural yang ada di wilayah pesisir.

\section{HASIL DAN PEMBAHASAN}

\section{Analisis bahaya tingkat kerawanan banjir rob dari segi penutupan lahan}

Penutupan lahan (land cover) adalah perwujudan secara fisik (kenampakan visual) dari vegetasi, benda alami dan unsur-unsur budaya yang ada di permukaan bumi tanpa mempermasalahkan kegiatan manusia pada objek yang ada (Townshend dan Verge 1998). Di wilayah yang tingkat perkembangannya sangat pesat dan labil, penutupan lahan bersifat dinamis. Dinamika tingkat perkembangan ini disebabkan oleh faktor utamanya yaitu faktor manusia dan faktor alam itu sendiri yang mudah berubah. Perubahan yang berasal dari faktor manusia antara lain dipicu oleh tingkat aksebilitas, pesatnya laju pertumbuhan penduduk, jarak lokasi terhadap pusat kegiatan (infrastruktur). Faktor dari alam seperti iklim dan erosi sangat mempengaruhi perubahan di lahan yang labil terutama di daerah pantai atau sungai. Beberapa pendekatan yang digunakan dalam penutupan lahan ialah pendekatan fungsional yang berorientasi pada kegiatan pertanian, kehutanan, perkotaan dan pendekatan morfologi yang menjelaskan penutupan lahan dengan memakai beberapa istilah seperti, lahan rumput, lahan hutan, lahan sawah, areal dibangun dan lainnya (Lo 1995).

Analisis bahaya banjir rob dapat dilakukan dengan pendekatan geomorfologi (Gunardi, 2009 dan Rafiuddin, 2010). Geomorfologi terdiri dari tiga suku kata pembentukannya yaitu Geo, Morpho dan logi yang merupakan ilmu yang mempelajari tentang bentuk lahan, termasuk sejarah dan proses pembentukannya. Aspek bentuk lahan dapat dianalisis dari aspek morfogenesis dan morfologi. Berdasarkan morfogenesisnya, bentuk lahan yang memiliki tingkat bahaya paling tinggi adalah fluvial seperti gosong pasir, dataran banjir minor, dataran minor tertinggalkan, dan dataran rawa, sedangkan bahaya paling rendah adalah fluvio antropogenik (daratan fluvial teraggradasi), karena memiliki elevasi lebih tinggi (Pramulya 2010). Demikian juga berdasarkan morfologi lahan, dapat dikategorikan bahwa lahan dengan interval ketinggian 0-1 m mempunyai tingkat bahaya rob yang tinggi. Hal ini menjelakan semakin rendah ketinggian lahan, maka tingkat bahaya semakin tinggi dan begitu juga sebaliknya.

\section{Analisis bahaya tingkat kerawanan banjir rob dari segi garis pantai}

Garis pantai (shoreline) adalah garis yang dibentuk oleh perpotongan antara air laut dengan daratan pantai. Garis pantai selalu berubah-ubah dari waktu ke waktu, baik perubahan sementara akibat pasang surut maupun perubahan permanen dalam jangka waktu panjang akibat abrasi dan akresi pantai atau keduanya (Pratikto 2004). Penyebab perubahan garis pantai dipengaruhi oleh faktor alami dan manusiawi. Faktor alami terdiri dari sedimentasi, abrasi, pemadatan sedimen pantai dan kondisi geologi. King (1974) menyebutkan bahwa secara umum ada tiga hal yang berpengaruh terhadap faktor alami pada perubahan fisik pantai yaitu gelombang, pasang surut, dan angin. Faktor manusiawi meliputi penanggulangan pantai, reklamasi (pengurugan pantai), penggalian sedimen pantai, penimbunan pantai, pembabatan hutan bakau pelindung pantai, pembuatan kanal banjir dan juga pembangunan pelabuhan atau bangunan pantai lainnya.

Secara garis besar perubahan pantai ada dua macam yaitu perubahan maju dan perubahan mundur. Garis pantai dikatakan bergerak maju (akresi) apabila terjadi pengendapan substrat pantai akibat penambahan material hasil endapan dari sungai dan laut. Garis pantai dikatakan mundur apabila terjadi proses pengikisan atau penggerusan 
pantai (abrasi) karena pengaruh dinamika pergerakan laut seperti gelombang dan hempasan ombak (Pardjaman, 1977 dalam Hildaliyani 2011). Upaya penanggulangan erosi pantai antara lain dengan dibangunnya tembok laut sea wall atau pelindung tebing revetment, krib tegak lurus pantai groin dan pemecah gelombang sejajar pantai (Pratikto, 2004). Namun demikian, upaya untuk melindungi erosi pantai seperti pembuatan pembangunan pelindung pantai juga dapat menimbulkan masalah erosi pantai baru disekitarnya. Perubahan-perubahan garis pantai yang terjadi dapat diinterpretasikan dan dipetakan dari citra satelit. Perubahan garis pantai berupa penambahan dan pengurangan areal tiap tahun yang dapat dihitung dan dipantau dari rekaman satelit yang berupa citra (Hermanto 1986).

\section{Analisis bahaya tingkat kerawanan banjir rob dari segi pasang surut}

Pasang surut adalah pergerakan permukaan air laut arah vertikal yang disebabkan pengaruh gaya tarik bulan, matahari dan benda angkasa terhadap bumi (Sarbidi, 2002). Gerakan permukaan air laut berperiodik sesuai gaya tariknya, intensitas gaya tarik akan berfluktuasi sesuai posisi bulan, matahari dan bumi. Posisi bulan dan bumi akan mempengaruhi besar kecilnya tunggang air. Tunggang air (tidal range) yaitu perbedaan tinggi air antara pasang maksimum (high water) dan pasang minimum (low water) disebut tunggang air dengan tinggi air rata-rata mencapai dari beberapa meter hingga puluhan meter. Puncak gelombang disebut pasang maksimum dan lembah gelombang disebut pasang minimum (Wibisono, 2005). Pasang terutama disebabkan oleh adanya gaya tarik menarik antara dua tenaga yang terjadi di lautan, yang berasal dari gaya sentrifugal yang disebabkan oleh perputaran bumi pada sumbunya dan gaya gravitasi yang berskala dari bulan. Gaya sentrifugal adalah suatu tenaga yang didesak ke arah luar dari pusat bumi yang besarnya lebih kurang sama dengan tenaga yang ditarik ke permukaan bumi. Tidak sama halnya dengan gaya tarik gravitasi bulan di mana gaya ini terjadi tidak merata pada bagian-bagian permukaan bumi. Gaya ini lebih kuat terjadi pada daerah-daerah yang letaknya lebih dekat dengan bulan, sehingga gaya yang terbesar terdapat pada bagian bumi yang terdekat dengan bulan dan gaya yang paling lemah terdapat pada bagian yang letaknya terjauh dari bulan. Gaya tarik gravitasi menarik laut ke arah bulan dan matahari dan menghasilkan dua tonjolan (bulge) pasang surut gravitasional di laut. Lintang dari tonjolan pasang surut ditentukan oleh deklinasi, sudut antara sumbu rotasi bumi dan bidang orbital bulan dan matahari (Hutabarat dan Evans, 1988).

Periode pasang surut adalah waktu antara puncak atau lembah gelombang ke puncak atau lembah gelombang berikutnya. Nilai periode pasang surut bervariasi antara 12 jam 25 menit hingga 24 jam 50 menit. Pasang purnama (spring tide) terjadi ketika bumi, bulan dan matahari berada dalam suatu garis lurus. Pada saat itu akan dihasilkan pasang tinggi yang sangat tinggi dan pasang rendah yang sangat rendah. Pasang purnama ini terjadi pada saat bulan baru dan bulan purnama. Pasang perbani (neap tide) terjadi ketika bumi, bulan, dan matahari membentuk sudut tegak lurus. Pada saat itu akan dihasilkan pasang tinggi yang rendah dan pasang rendah yang tinggi. Pasang surut perbani ini terjadi pada saat bulan $1 / 4$ dan $3 / 4$. Sistem pasang surut purnama (spring tide) dan perbani (neap tide) dijelaskan pada Gambar 1 (Karl, 2002).
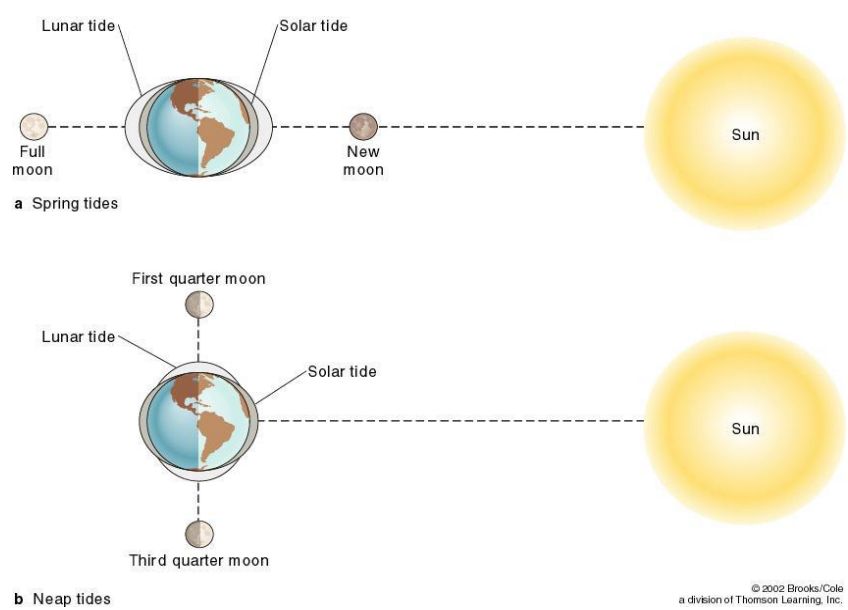

Gambar 1. Sistem pasang surut purnama (spring tide) dan perbani (neap tide)

Berdasarkan pola gerakan muka lautnya, pasang surut di dapat dibagi menjadi empat jenis yaitu pasang surut harian tunggal (diurnal), harian ganda (semi diurnal) dan dua jenis campuran (mixed tides). Pada jenis harian tunggal terjadi satu kali pasang dan satu kali surut dalam sehari, saat spring dapat terjadi dua kali pasang sehari. Pada jenis harian ganda terjadi dua kali pasang sehari dengan tinggi pasang dan surut yang relatif sama. Pada pasang surut campuran terdapat dua jenis yaitu campuran tunggal (mixed tide prevalling diurnal dan campuran ganda (mixed tide prevalling semi diurnal). Pasang surut campuran tunggal terjadi satu atau dua kali pasang sehari dengan interval yang berbeda, 
sedangkan pada campuran ganda terjadi dua kali pasang sehari dengan perbedaan tinggi dan interval yang berbeda. Dalam sebulan, variasi harian dari rentang pasang surut berubah secara sistematis terhadap siklus bulan. Rentang pasang surut juga sangat bergantung sekali pada bentuk perairan dan konfigurasi lantai samudera.

Pasang surut bersifat periodik, data amplitudo dan beda fase dari komponen pembangkit pasang surut dibutuhkan untuk meramalkan pasang surut. Komponen-komponen utama pasang surut terdiri dari komponen tengah dan harian. Namun demikian, karena interaksinya dengan bentuk morfologi pantai dan superposisi antar gelombang pasang surut komponen utama, terbentuk komponen-komponen pasang surut yang baru.

\section{Analisis bahaya tingkat kerawanan banjir rob dari segi kenaikan muka laut}

Kenaikan muka laut merupakan fenomena naiknya muka air laut terhadap rata-rata muka laut (titik acu benchmark di darat) akibat dari pertambahan volume air laut. Perubahan tinggi permukaan air laut dapat dilihat sebagai suatu fenomena alam yang terjadi secara periodik maupun menerus. Perubahan secara periodik dapat dilihat dari fenomena pasang surut air laut, sedangkan kenaikan air laut yang menerus adalah seperti yang teridentifikasi oleh pemanasan global. Fenomena naiknya muka laut yang direprsentasikan dengan SLR (sea level rise) dipengaruhi secara dominan oleh pemuaian thermal (thermal expansion) sehingga volume air laut bertambah. Selain itu, mencairnya es di kutub dan gletser juga memberikan kontribusi terhadap perubahan kenaikan muka laut. Beberapa tahun terakhir ini, perubahan sea level rise di estimasi dari pengukuran dari stasiun pasang surut (Nurmaulia et al. 2006). Dampak yang terjadi secara permanen antara lain perubahan kondisi ekosistem pantai, meningkatnya erosi, makin cepatnya kerusakan yang terjadi bergantung pada tingkat dan jenis pemanfaatan kawasan tepi pantai.

Menurut IPCC (Intergovernmental Panel on Climate Change) memperkirakan bahwa pada kurun waktu 100 tahun terhitung mulai tahun 2000 permukaan air laut akan meningkat setinggi $15-90 \mathrm{~cm}$ dengan kepastian peningkatan setinggi $48 \mathrm{~cm}$. Apabila perkiraan IPCC tentang kenaikan muka laut terjadi, maka diperkirakan Indonesia akan kehilangan 2.000 pulau. Hal ini pula yang akan menyebabkan mundurnya garis pantai di sebagian besar wilayah Indonesia (Mimura 2000). Indonesia merupakan negara kepulauan dengan mayoritas populasinya terbesar di sekitar wilayah pesisir. Dampak negatif yang dapat dirasakan langsung dari fenomena kenaikan muka laut diantaranya erosi garis pantai, penggenangan wilayah daratan, meningkatnya frekuensi dan intensitas banjir, meningkatnya dampak badai di daerah pesisir, salinisasi lapisan akuifer dan kerusakan ekosistem wilayah pesisir. Meskipun demikian sampai saat ini karakteristik serta perilaku dari fenomena naiknya muka laut di wilayah region perairan Indonesia belum dipahami secara baik dan komprehensif. Jadi, perilaku kedudukan muka laut baik variasi temporal maupun spasialnya di wilayah Indonesia merupakan salah satu informasi penting yang diperlukan untuk perencanaan dan pelaksanaan pembangunan suatu wilayah secara berkelanjutan.

\section{Analisis bahaya tingkat kerentanan fisik}

Kerentanan fisik (infrastruktur) menggambarkan perkiraan tingkat kerusakan terhadap fisik bila ada faktor berbahaya (hazard) tertentu. Tingkat kerentanan fisik dapat dilihat dari berbagai indikator antara lain persentase kawasan terbangun; kepadatan bangunan; persentase bangunan konstruksi darurat; jaringan listrik; rasio panjang jalan; jaringan telekomunikasi; jaringan PDAM; dan jalan kereta api. Apabila persentase dari berbagai indikator tersebut rendah,maka dikatakan wilayah tersebut rentan terhadap bencana yang ada. Indikator-indikator penilaian tingkat kerentanan fisik dibuktikan dengan kondisi di lapangan. Macam indikator yang digunakan untuk meniai tingkat kerentanan fisik seperti konstruksi rumah yang non permanen memiliki tingkat kerentanan tinggi, sedangkan rumah yang berkonstruksi semi-permanen dapat berada pada tingkat kerentanan sedang; sarana umum tingkat kerentanan fisik diturunkan menggunakan indikator-indikator yang meliputi jalan, sarana air bersih, sarana pendidikan dasar, sarana kesehatan dan sarana sanitasi yang dinilai berdasarkan pada kemungkinan kerusakan saat terkena rob; bangunan pelindung yang terdapat di suatu daerah berupa tanggul, pemecah gelombang (breaker water), polder, pintu air yang semakin banyak bangunan pelindung di suatu wilayah, semakin rendah tingkat kerentanan di wilayah tersebut; tingkat kerentanan berdasarkan letak geografis dinilai menggunakan indikator jauh atau dekatnya lokasi dengan laut atau sungai yang biasa dibuktikan dengan data ketinggian rob yang ada.

\section{Analisis bahaya tingkat kerentanan sosial}

Kerentanan sosial menunjukkan perkiraan tingkat kerentanan terhadap keselamatan jiwa atau kesehatan penduduk apabila ada bahaya. Kerentanan sosial dapat dilihat dengan menggunakan indikator-indikator seperti komposisi penduduk, mata pencaharian, tingkat keamanan, dan sistem sosial. Komposisi penduduk bisa digunakan sebagai indikator penilaian tingkat kerentanan meliputi penduduk usia lanjut, anak-anak, dewasa dengan komposisi antara laki-laki dan perempuan; tingkat pendidikan; kepadatan penduduk. Mata pencaharian yang tetap menyebabkan adanya penghasilan yang tetap pula, sedangkan mata pencaharian yang tidak tetap akan menyebabkan penghasilan yang tidak menentu. Penduduk yang memiliki mata pencaharian tetap akan memiliki tingkat kerentanan yang rendah dibandingkan dengan masyarakat yang tidak berpenghasilan tetap. Tingkat keamanan yang tinggi akan menjadikan tingkat kerentanan yang rendah jika terjadi bencana rob, begitu pula sebaliknya. Hal tersebut dapat digambarkan jika 
terjadi bencana rob, maka penduduk yang hidup aman, rukun dan berdampingan tersebut akan saling membantu. Penilaian tingkat kerentanan dapat pula dilakukan dengan menginventarisir adanya pos kampling dan keberadaan regu ronda. Sistem sosial yang digunakan untuk menilai tingkat kerentanan wilayah meliputi kegiatan gotong royong dan kesadaran masyarakat terhadap lingkungannya. Kegiatan gotong royong yang ada merupakan kegiatan saling membantu antar warga yang terkena bencana rob, sedangkan kesadaran masyarakat terhadap lingkungan biasanya diwujudkan dengan kegiatan bersih-bersih di sekitar rumah dan saluran-saluran air.

\section{Analisis bahaya tingkat kerentanan ekonomi}

Kerentanan ekonomi menggambarkan besarnya kerugian atau rusaknya kegiatan ekonomi (proses ekonomi) yang terjadi bila terjadi ancaman bahaya. Indikator yang dapat kita lihat menunjukkan tingginya tingkat kerentanan misalnya adalah persentase rumah tangga yang bekerja di sektor rentan (sektor jasa dan distribusi) dan persentase rumah tangga miskin. Tingkat kerentanan dapat dibedakan menjadi tiga, yaitu tingkat kerentanan tinggi, sedang dan rendah. Indikator yang digunakan untuk menilai tingkat kerentanan ekonomi seperti persentase penggunaan lahan untuk pertanian, penyokong ekonomi keluarga, tingkat pendapatan, keberadaan industri kecil menengah dan juga keberadaan koperasi.

\section{Analisis bahaya tingkat ketahanan struktural}

Ketahanan struktural menggunakan beberapa variabel yang dijadikan indikator dalam menentukan kesiapsiagaan warga masyarakat desa dan pemerintah desa dalam menghadapi banjir rob. Keberadaan bangunan pelindung, cara perbaikan rumah, dan bagaimana perbaikan infrastruktur desa yang rusak akibat rob menghasilkan tingkat kemampuan masyarakat yang berbeda. Daerah yang memiliki bangunan pelindung yang lengkap akan memiliki kemampuan yang tinggi dalam menghadapi bencana rob, sedangkan bangunan pelindung tidak lengkap menghasilkan kemampuan tingkat sedang ataupun rendah. Keberadaan bangunan pelindung yang dapat menahan bencana rob dianggap penting agar air tidak menyebar dan menyebabkan kerugian pada pemukiman warga. Bangunan pelindung ini dapat berupa polder, tanggul air, dan pintu air. Bangunan tersebut bervariasi masing-masing daerah. Setiap daerah dapat mempunyai satu jenis bangunan pelindung, tetapi terdapat desa yang mempunyai dua atau bahkan tiga jenis bangunan pelindung.

Keberadaan tanggul sungai menjadi salah satu kunci utama dalam menekan dampak negatif banjir rob. Dengan adanya tanggul sungai ini luapan air laut yang masuk melalui aliran sungai dapat tertahan. Tanggul sungai ini dibedakan berdasarkan bahan materialnya, yaitu beton, bronjong, dan karung goni. Pemilihan material bangunan tanggul ini akan mempengaruhi ketahanan bangunan dalam menahan rob. Sementara itu, pintu air yang dibangun di beberapa titik pada aliran sungai dapat menjadi pengontrol terhadap ketinggian air yang masuk ke sungai. Dengan adanya pintu air ini maka air laut yang masuk pada saat pasang akan dapat dibatasi agar jumlahnya tidak melebihi ambang batas. Hal ini sangat bermanfaat bagi desa-sesa yang dilalui oleh aliran air sungai. Peninggian lantai rumah menjadi cara paling banyak dilakukan warga untuk mengurangi masuknya air rob sampai ke dalam rumah. Peninggian lantai masing-masing daerah berbeda (misalnya dapat mencapai 70 centimeter) tergantung pada tinggi air rob. Peninggian ini terus dilakukan seiring dengan kenaikan air rob dan banjir. Dilihat dari persiapan warga melakukan peninggian lantai ini maka antisipasi warga terhadap rob berada pada tingkat ketahanan yang tinggi.

\section{Analisis bahaya tingkat ketahanan sosial}

Ketahanan masyarakat pada aspek sosial ini dikaji dengan menganalisis sistem sosial masyarakat dalam menghadapi rob, terutama bagaimana masyarakat melakukan perbaikan rumah dan infrastruktur desa yang rusak terkena rob, tingkat pengetahuan masyarakat mengenai rob, serta jenis bantuan pemerintah kepada warga menghadapi rob. Dalam hal perbaikan rumah, maka tergantung sistem sosial yang ada di masyarakat. Misalnya kebiasaan dalam masyarakat untuk melakukan gotong royong membantu warga masyarakat lain dalam membangun dan memperbaiki rumah. Gotong royong merupakan salah satu wujud sikap tenggang rasa antar warga masyarakat yang telah mengakar kuat dalam budaya masyarakat Indonesia. Dalam upaya perbaikan infrastruktur desa, masyarakat lebih melihat bahwa infrastruktur desa merupakan sarana prasarana yang menjadi bagian dari milik bersama sehingga warga masyarakat lebih merasa ikut bertanggung jawab dan menjaganya secara bergotong royong.

Pengetahuan warga dalam mengenal datangnya suatu bencana akan berpengaruh terhadap kesiapsiagaan mereka dalam menghadapi bencana tersebut. Pengetahuan ini berkaitan dengan kebiasaan membaca tanda-tanda alam terhadap datangnya bencana tersebut. Di berbagai daerah di Indonesia kearifan lokal masyarakat setempat dalam membaca tanda-tanda alam akan datangnya bencana telah menyelamatkan nyawa banyak orang. Namun tidak semua warga masyarakat mengetahui atau mencermati tanda-tanda tersebut. Bantuan makanan yang datang dari berbagai instansi pemerintah dan swasta berupa bahan makanan biasanya terjadi ketika skala bencana yang terjadi sangat besar sehingga menyebabkan warga masyarakat tidak dapat bekerja dalam mencukupi kebutuhan sehari-hari. Bangunan material bangunan sangat dibutuhkan warga masyarakat baik dalam memperbaiki rumah maupun sarana prasarana di desa mereka. Bantuan tenaga dalam hal ini adalah keberadaan Taruna Tanggap Bencana (Tagana) yang siap siaga 
apabila banjir rob terjadi dalam skala yang besar. Keberadaan Tagana ini sangat dibutuhkan dalam mendistribusikan bantuan ke desa-desa yang membutuhkan. Selain itu, Tagana juga membantu dalam perbaikan fasilitas publik pada desa tersebut.

\section{Analisis bahaya tingkat ketahanan ekonomi}

Tingkat ketahanan ekonomi ini dianalisis berdasarkan variabel dampak rob terhadap aktivitas perekonomian masyarakat, bentuk bantuan modal usaha dan padat karya dalam usaha perbaikan kerusakan akibat rob serta ketersediaan anggaran untuk biaya perbaikan terhadap kerusakan rob. Warga masyarakat yang bermukim di semua desa yang terkena banjir rob menyebabkan terganggunya aktivitas keseharian mereka. Hal ini menyebabkan tingkat pendapatan warga juga mengalami penurunan. Selain itu, rob juga menyebabkan kerusakan pada fasilitas umum dan kendaraan bermotor yang menyebabkan lalu lintas warga masyarakat terganggu. Dengan demikian masyarakat yang bekerja pada sektor informal harus mempunyai cadangan pekerjaan yang lain agar dapat memenuhi kebutuhan pada saat rob. Bencana rob menyebabkan masyarakat harus memiliki anggaran dalam upaya perbaikan rumah dan perabot rumah tangga mereka yang rusak. Masyarakat membutuhkan dana yang cukup besar agar dapat membiayai seluruh kerusakan yang ada. Jumlah pengeluaran tiap warga untuk memperbaiki rumah yang rusak terkena rob, bervariasi. Hal ini dipengaruhi oleh besarnya perbaikan yang mereka lakukan dan tingkat pendapatan. Persebaran ketahanan ekonomi dapat berada pada tingkat rendah, sedang dan tinggi.

\section{Analisis bahaya tingkat mitigasi struktural}

Mitigasi struktural adalah upaya-upaya pengurangan risiko bencana yang lebih bersifat fisik (Rahayu et all, 2009). Menurut Mardiatno et all (2012) upaya-upaya mitigasi struktural banjir rob dapat dilakukan dengan beberapa cara diantaranya perlindungan alami (mangrove, terumbu karang, dan gumuk pasir), perlindungan buatan (pemecah gelombang, tanggul, tembok laut dan konstruksi perlindungan pantai lainnya). Sementara itu Rahayu et all (2009) menguraikan upaya untuk mitigasi banjir dilakukan oleh pemerintah, antara lain: (1) perbaikan dan peningkatan sistem drainase, (2) normalisasi fungsi sungai yang dapat berupa pengerukan, sudetan; (3) relokasi pemukiman di bantaran sungai; (4) pengembangan bangunan pengontrol tinggi muka air/hidrograf banjir berupa tanggul, pintu, pompa, waduk dan sistem polder (polder merupakan salah satu bentuk bangunan yang dapat dipergunakan untuk melindungi kawasan dari kenaikan air laut). Teknologi ini sudah diterapkan di negara-negara maju, seperti Belanda untuk mencegah masuknya air laut ke daerah daratan; (5) perbaikan kondisi Daerah Aliran Sungai (DAS). Mitigasi struktural yang dapat dilakukan oleh masyarakat di kawasan rawan banjir, antara lain: (1) membantu upaya peningkatan kapasitas resapan air di wilayahnya baik dengan menanam lebih banyak pohon maupun membuat sumur resapan; (2) membantu penyusunan peta zonasi/risiko banjir; (3) membangun rumah sesuai dengan peraturan tata guna lahan; (4) membuat rumah lebih tinggi dari muka air banjir; (5) melengkapi sistem sanitasi rumah dengan penutup banjir.

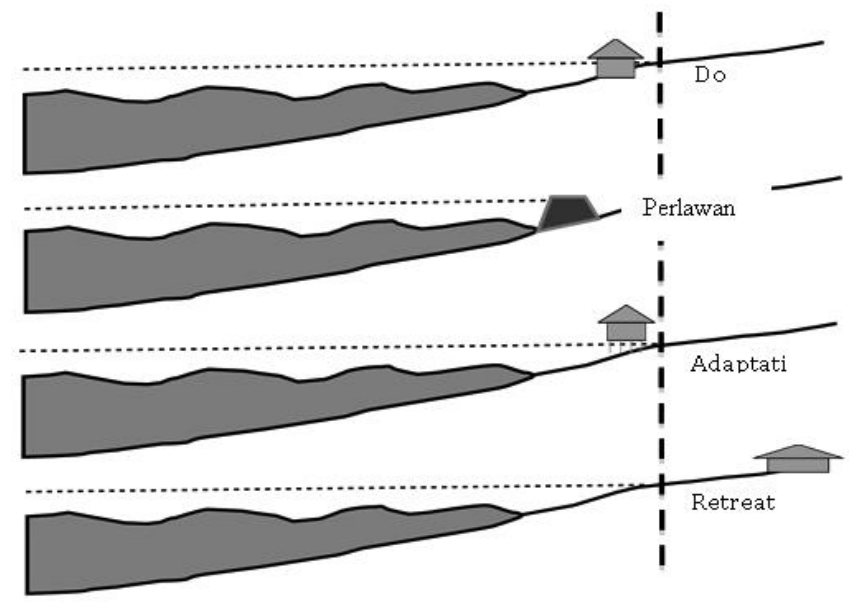

Gambar 2. Berbagai bentuk strategi adaptasi yang dilakukan oleh masyarakat

\section{Analisis bahaya tingkat mitigasi non struktural}

Mitigasi non struktural adalah segala upaya pengurangan risiko bencana yang dilakukan yang bersifat non fisik, organisasional dan social kemasyarakatan (Rahayu et all, 2009). Upaya-upaya mitigasi non struktural banjir yang 
dilakukan oleh pemerintah, antara lain: (1) membuat master plan pembangunan yang berbasis pengurangan risiko bencana; (2) membuat PERDA mengenai penanganan risiko bencana banjir berkelanjutan; (3) mengembangkan peta zonasi banjir; (4) mengembangkan sistem asuransi banjir; (5) membangun/memberdayakan Sistem Peringatan Dini Banjir; (6) meningkatkan pengetahuan masyarakat mengenai bencana banjir melalui pendidikan dan pelatihan; (7) mengembangkan building code bagi daerah banjir. Mitigasi non fisik dapat pula dilakukan melalui kegiatan pendidikan lingkungan yaitu (1) mewujudkan budaya masyarakat dan pemangku kepentingan dalam memahami fenomena banjir dan menjaga kapasitas/kelestarian daya serap Daerah Aliran Sungai (DAS); (2) mewujudkan budaya masyarakat untuk berperan serta dalam menjaga fungsi sistem pembuangan air (drainase) dan pengendalian banjir; (3) mewujudkan budaya masyarakat yang tidak membuang sampah ke sungai, saluran dan bangunan air lainnya; (4) melakukan gerakan penghijauan atau penanaman kembali tumbuh tumbuhan di lahan yang kosong dan memelihara dengan baik; (5) mengutamakan upaya pengurangan risiko bencana banjir dalam kurikulum pendidikan.

Adapun bentuk upaya mitigasi non struktural yang dapat dilakukan oleh masyarakat di kawasan rawan banjir, antara lain: mengerti akan ancaman banjir termasuk banjir yang pernah terjadi dan mengetahui letak daerah apakah cukup tinggi untuk terhindar dari banjir; mengembangkan diri dengan mengikuti pelatihan-pelatihan dalam menghadapi bencana, seperti pelatihan pertolongan pertama pada kondisi tanggap darurat; berperan aktif pada aktifasi posko banjir. Menurut Mardiatno et all, (2012) upaya mitigasi non-stuktur dapat ditempuh dengan penataan ruang yang tercermin dalam penggunaan lahan, pembuatan peta rawan bencana banjir rob, zonasi kawasan konservasi dan budidaya, pembuatan sepadan pantai dan sungai. Selain itu perlu adanya diseminasi informasi dan penyuluhan publik terkait upaya mitigasi bencana kepesisiran (termasuk early warning system), pengelolaan kepesisiran dan kelautan yang terintegrasi dengan sector pembangunan dan lainnya, termasuk didalamnya adalah upaya pengentasan kemiskinan serta relokasi permukiman yang terkena $r o b$.

\section{KESIMPULAN}

Berdasarkan pada hasil pengkajian dan pembahasan yang telah dilakukan terhadap banjir rob, maka potensi kerentanan pada lingkungan serta penanggulangannya dapat ditarik beberapa kesimpulan, antara lain :

1. Banjir pasang ( $r o b)$ merupakan banjir yang terjadi karena naiknya air laut dan menggenangi daratan ketika air laut mengalami pasang sehingga dapat menyebabkan beberapa kerentanan terhadap lingkungan.

2. Kerentanan lingkungan yang bisa ditimbulkan meliputi kerentanan fisik (physical vulnerability), kerentanan sosial (social vulnerability) dan kerentanan ekonomi (economic vulnerability).

3. Beberapa upaya pendekatan untuk penanggulangan kerentanan terhadap lingkungan dapat dilakukan dengan cara yaitu ketahanan struktural, ketahanan sosial, ketahanan ekonomi, mitigasi struktural dan juga mitigasi nonstruktural.

\section{DAFTAR PUSTAKA}

Bourgeois R, F Jesus. 2004. Participatory prospective analysis: Exploring and anticipating challenges with stakeholders. The United Nation: CAPSA Monograph No. 46.

Cardona. 2003. The need for rethinking the concepts of vulnerability and risk from a holistic perspective: necessary review and critics for effective risk management.

Fedra K. 2004. Coastal zone resource management: tools for a participatory planning and decision making process. Littoral 2004, Aberdeen, Scotland, UK: 1-6.

Hildaliyani. 2011. Analisis daerah genangan banjir rob (pasang) di pesisir utara Jakarta menggunakan data citra satelit SPOT dan ALOS. [Skripsi] Institut Pertanian Bogor.

Japan Aerospace Exploration Agency (JAXA). 2007. ALOS user handbook. Earth observation research center. Tsakuba-city.

Kobayashi H. 2001. Penilaian jumlah dampak kenaikan muka air laut di perkotaan-kasus Makassar dan Semarang. Research center for advanced information of technology. Nasional institute for land and infrastructure management (NILIM), Ministry of land and infrastructure and transport. Japan.

Lewis J. 1997. Development, vulnerability, and disaster reducation. Bangladesh's cycloon shelter project and their implication, Chapter 4 in reconstruction after disaster: issues and practices. Awotona. Adenrele. Ed. Ashgate ISBN 1-85972-551.

Lo CP. 1995. Penginderaan Jauh Terapan. UI Press. Jakarta. 
Mardiatno D, M Aris M, Kusuma R, Riski T, Riswan SS, Yosi SM. 2012. Program S2-perencanaan dan pengelolaan pesisir dan DAS (MPPDAS). Penilaian multirisiko banjir dan rob di Kecamatan Pekalongan Utara. Universitas Gadjah Mada.

Martin K, M Hall-Arber. 2008. The missing layer: Geo-technologies, communities, and implications for marine spatial planning. Marine pollution 32: 779-786.

Nurmaulia SL, Prijatna K, Darmawan D, Sarsito DA. 2006. Studi awal perubahan kedudukan muka laut (sea level change) di perairan Indonesia berdasarkan data satelit altimetri TOPEX (1992-2002). Institut Teknologi Bandung. Bandung.

Pramulya M. 2010. Analisis daerah bahaya dan risiko banjir berdasarkan karakteristik geomorfologi dan aplikasinya untuk evaluaasi tata ruang Kota Sintang. [Tesis] sekolah pascasarjana IPB. Bogor.

Pratikto WA. 2004. Pedoman penyusunan rencana pengelolaan garis pantai Direktorat Jenderal Pesisisr dan PulauPulau Kecil. Departemen Kelautan dan Perikanan Republik Indonesia.

Rafiuddin A. 2010. Pemanfaatan penginderaan jauh dan system infomasi geografi untuk kajian bahaya dan resiko bencana alam di kota Bogor. IPB

Rahayu HP. 2009. Banjir dan upaya penanggulangannya. PROMISE Indonesia (Program for Hydro - Meteorogical Risk Mitigation Secondary Cities in Asia). Bandung.

Rustiadi E, S Saefulhakim, DR Panuju. 2009. Perencanaan dan pengembangan wilayah. Crespent Press dan Yayasan Obor Indonesia. Jakarta.

Sarbidi. 2002. Pengaruh ROB pada pemukiman pantai (Kasus Semarang). Pusat Penelitian dan Pengembangan Pemukiman.

Smith K, Petley DN. 2009. Environmental hazards: assessing risk and reducing disaster, fifth edition, Routledge. New York USA.

Soedarsono S. 2006. Impact of flood inundation due to sea-level rise on the settlement area in Semarang City (in Indonesia). Master thesis. Geography faculty Gadjah Mada University. Indonesia.

Suryanti ED, Marfai MA. 2008. Adaptasi masyarakat kawasan pesisir Semarang terhadap bahaya banjir pasang air laut (Rob). Jurnal kebencanaan Indonesia 1(5): 335-346.

Sutherland A. 1998. Participatory research in natural resources. Socio-economic methodologies. Best practice guidelines. Chatham. UK: Natural Resources Institute.

Taussik J. 2004. Changes to the planning system that impact on the management of coastal risk: A research paper for the local government association's special Interest group on coastal issues. Research paper 1: changes to the planning system. UK: LGA CSIG.

Trisakti B, Pradana FA. 2007. Pengembangan aplikasi data 3D dari satelit optik (ALOS dan ASTER). Laporan akhir LAPAN.

Walz A, C Lardelli, H Behrendt, A Grêt-Regamey, C Lundströma, S Kytzia, P Bebi. 2007. Participatory scenario analysis for integrated regional modelling. Lands. Urb. Planning. 81: 114-131. 